\title{
Analysis of exhaust emissions in the real operating conditions of a public transport vehicle with the use of PEMS
}

\author{
Analiza emisji spalin w rzeczywistych warunkach pracy pojazdu \\ komunikacji zbiorowej z wykorzystaniem PEMS
}

\begin{abstract}
The paper discusses the issues related to the measurement of the operating parameters of a conventional engine and the parameters of a conventional bus in motion. The measurements were performed under actual traffic conditions of a city bus in Poznan'. It is noteworthy that onroad tests under actual operating conditions (PEMS) are one of the main trends of the development of the testing methodology and are gradually gaining in importance. Specific conditions were selected to ensure the highest possible reflection of the actual conditions: the traffic similar to the traffic typical of a regular bus route (average traffic on Poznan routes). The tests were conducted for two days (Friday and Saturday), characteristic of very high and very low number of transported people respectively as well as high and medium traffic congestion. During the tests the engine and the driving parameters were recorded continuously as sent from the diagnostic system of the vehicle and the GPS. The PEMS test method (portable emissions measurement system) presented in the article can be used in the measurement of exhaust emissions in rail vehicles with combustion engines.

W artykule omówiono zagadnienia zwiqzane z pomiarem wskaźników pracy silnika oraz parametrów konwencjonalnego autobusu $w$ ruchu. Pomiary wykonano $w$ rzeczywistych warunkach ruchu autobusu miejskiego w Poznaniu. Warto zauważyć, że badania drogowe w rzeczywistych warunkach eksploatacyjnych PEMS (Portable Emissions Monitoring System) sq jednym z głównych trendów rozwoju metodologii badań i stopniowo zyskuja na znaczeniu. Specyficzne warunki zostaty dobrane tak, aby jak najlepiej odzwierciedlić stan faktyczny: ruch zbliżony do ruchu typowego dla zwyktej linii autobusowej (przeciętny ruch na trasach poznańskich). Testy byty prowadzone przez dwa dni (piatek i sobote), charakteryzujace się odpowiednio bardzo duż $i$ bardzo mała liczba przewożonych osób oraz dużym i średnim natężeniem ruchu. W trakcie testów silnik $i$ parametry jazdy rejestrowane byly $w$ sposób ciagly przesyłane z systemu diagnostycznego pojazdu i GPS. Przedstawiona w artykule metoda badawcza PEMS (badania emisji spalin $w$ warunkach rzeczywistych) może zostać wykorzystana $w$ pomiarze emisji spalin także $w$ pojazdach szynowych o napędzie spalinowym.
\end{abstract}

\section{Introduction}

The Exhaust emission tests related to diesel engines designed for vehicles of the GVW exceeding $3500 \mathrm{~kg}$ (table 1) are carried out on an engine dynamometer (Fig. 1). The tested engines are mainly direct injection engines (HDD-DI - Heavy Duty Diesel Direct Injection). The currently applicable exhaust emissions directive 88/77/EWG with the amendment 2001/27/WE applies to diesel vehicles, NG fueled vehicles and spark ignition vehicles fueled with LPG. The homologation covers the exhaust emissions and the fitting configuration of the engine inside the vehicle. The ECE R49 test still used in the European countries has now been replaced with two tests: stationary ESC (European Stationary Cycle) and transient ETC (European Transient Cycle). The opacity measurement is done in the ELR test (European Load Response). The transient speed ECE R49 is determined as follows: a)

\section{Wstęp}

Badania silników ZS przeznaczone do napędu pojazdów o dopuszczalnej masie całkowitej powyżej 3500 $\mathrm{kg}$ (tab. 1) pod względem toksyczności spalin wykonuje się na hamowni silnikowej (rys. 1). Są głównie silniki o bezpośrednim wtrysku paliwa do komory spalania (HDD-DI - Heavy Duty Diesel Direct Injection). Obowiązująca obecnie w zakresie emisji spalin dyrektywa 88/77/EWG z poprawką 2001/27/WE dotyczy pojazdów napędzanych silnikami ZS, pojazdów napędzanych silnikami zasilanymi NG i pojazdów napędzanych silnikami ZI zasilanymi LPG. Homologacji podlega emisja spalin z silnika oraz zabudowa silnika w pojeździe. Test ECE R49 obowiązujący jeszcze do niedawna w krajach europejskich został zastapiony przez dwa testy: stacjonarny ESC (European Stationary Cycle) oraz test dynamiczny ETC (European Transient Cycle). Pomiar zaczernienia spalin wykonuje się w 
if the condition $0,6 \mathrm{nNe} \max <\mathrm{nMo} \max <0,75 \mathrm{nNe}$ max is fulfilled then the transient speed is the speed of the maximum torque, $\mathrm{b}$ ) if $\mathrm{nMo} \max <0,6 \mathrm{nNe} \max$ then $\mathrm{n}$-transient $=0,6 \mathrm{nNe} \max$, if $\mathrm{nMo} \max >$ $0,75 \mathrm{nNe} \max$, then $\mathrm{n}$-transient $=0,75 \mathrm{nNe} \max$. The courses of these tests have been shown in figures 2 and 3.

Tab. 1 Europejskie kategorie pojazdów o masie calkowitej powyżej $3500 \mathrm{~kg}$

\begin{tabular}{|c|c|}
\hline Vehicle category & Description \\
\hline M3 - buses & $\begin{array}{c}\text { Vehicles of the seating capacity greater } \\
\text { than 9 } \\
\text { and GVW exceeding } 5000 \mathrm{~kg}\end{array}$ \\
\hline $\begin{array}{c}\text { N3 - heavy duty } \\
\text { vehicles (HDV) }\end{array}$ & $\begin{array}{c}\text { Vehicles of the GVW exceeding } \\
12000 \mathrm{~kg}\end{array}$ \\
\hline
\end{tabular}

The ESC test is carried out on an engine dynamometer in the order of the phases specified in figure 4. The preparation of the operating point is done in the first 20 seconds of the phase. The admissible error of the engine speed for the measuring point is $\pm 50 \mathrm{rpm}$ and torque $\pm 2 \% M_{o \text { max }}$ for the tested engine speed. The exhaust emissions are measured as a weighted average in the test (using the phase share coefficient). The time of operation of the engine at individual operating phases is two minutes (phase 1 is the exception as it lasts 4 minutes). Hence, the whole test lasts 28 minutes. The engine speeds are defined as follows (based on the full power characteristics):

- maximum engine speed $\left(n_{\max }\right)$

- upon exceeding the maximum power, when the engine reaches $70 \% N_{e \max }$,

- minimum engine speed $\left(n_{\min }\right)$ - the engine reaches $50 \% N_{e \max }$

- individual speeds for phases $A, B, C$ are calculated from the relation:

$$
\begin{aligned}
& \mathrm{A}=\mathrm{n}_{\text {min }}+0,25\left(\mathrm{n}_{\text {max }}-\mathrm{n}_{\text {min }}\right), \\
& \mathrm{B}=\mathrm{n}_{\text {min }}+0,50\left(\mathrm{n}_{\text {max }}-\mathrm{n}_{\text {min }}\right), \\
& \mathrm{C}=\mathrm{n}_{\text {min }}+0,75\left(\mathrm{n}_{\text {max }}-\mathrm{n}_{\text {min }}\right) .
\end{aligned}
$$
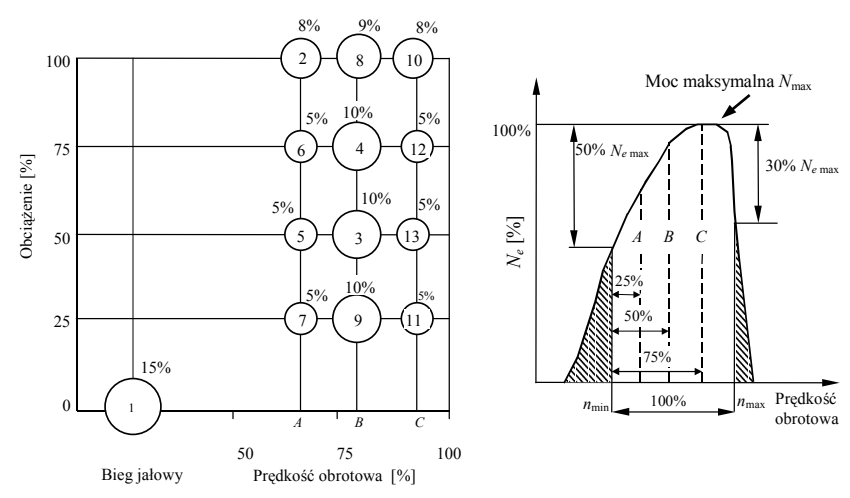

Fig. 2. The schematics of the ESDC stationary test

Rys. 2. Schemat stacjonarnego testu ESC teście ELR (European Load Response). Prędkość pośrednia $w$ teście ECE R49 jest wyznaczana następująco: a) jeżeli jest spełniony warunek $0,6 n_{N e \max }$ $<n_{M o}$ max $<0,75 n_{N e \max }$, to za prędkość pośrednią przyjmuje się prędkość obrotową maksymalnego momentu, b) jeżeli $n_{M o \max }<0,6 n_{N e} \max$, to $n_{\text {pośrednie }}=$ $0,6 n_{N e}$ max , jeżeli $n_{M o \text { max }}>0,75 n_{N e}$ max , to $n_{\text {pośrednie }}=$ $0,75 n_{N e}$ max. Przebiegi tych testów zamieszczono na rysunkach 2 i 3.

Tab. 1 Europejskie kategorie pojazdów o masie całkowitej powyżej $3500 \mathrm{~kg}$

\begin{tabular}{|l|l|}
\hline Kategoria pojazdu & Wyszczególnienie \\
\hline M3 - autobusy & $\begin{array}{l}\text { pojazdy o liczbie miejsc większej niż 9 } \\
\text { i masie całkowitej większej niż 5.000 } \\
\mathrm{kg}\end{array}$ \\
\hline $\begin{array}{l}\text { N3 - ciężkie pojazdy } \\
\text { dostawcze (HDV) }\end{array}$ & $\begin{array}{l}\text { pojazdy o masie całkowitej większej } \\
\text { niż 12.000 kg }\end{array}$ \\
\hline
\end{tabular}

Fig. 1. Engine dynamometer for the stationary and transient tests

Rys. 1. Hamownia silnikowa do testów dynamicznych i statycznych

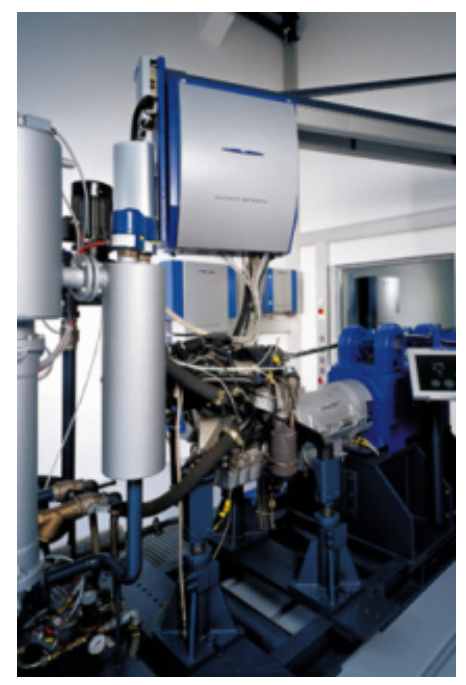

Test ESC jest wykonywany na hamowni silnikowej w kolejności faz określonych przedstawionych na rysunku 4. Przygotowanie punktu pracy odbywa się w pierwszych 20 sekundach fazy. Dopuszczalny błąd prędkości obrotowej dla punktu pomiarowego wynosi \pm 50 ob$\mathrm{r} /$ min, momentu obrotowego $\pm 2 \% M_{o \text { max }}$ dla badanej prędkości obrotowej. Emisja związków toksycznych jest mierzona jako średnia ważona $\mathrm{w}$ teście (z wykorzystaniem współczynników udziału faz). Czas pracy silnika w poszczególnych punktach pomiarowych (fazach) wynosi dwie minuty (wyjątek stanowi pierwsza faza -4 minuty), a więc cały test trwa 28 minut. Prędkości obrotowe są zdefiniowane następująco (na podstawie charakterystyki pełnej mocy):

- prędkość obrotowa maksymalna $\left(n_{\max }\right)$ - po przekroczeniu mocy maksymalnej, gdy silnik uzyskuje $70 \% N_{e \max }$, prędkość obrotowa minimalna $\left(n_{\min }\right)-$ silnik uzyskuje $50 \% N_{e \text { max }}$

- $\quad$ poszczególne prędkości faz $A, B, C$ oblicza się z zależności: 
Along with the ESC test, an opacity test is carried out in the ELR test (Fig. 3) - the characteristic measuring points were determined based on the ESC test scheme. The value of absorption coefficient $(k)$ is determined based on the calculation formula:

$$
\mathrm{k}=0,43 \mathrm{k}_{\mathrm{A}}+0,56 \mathrm{k}_{\mathrm{B}}+0,01 \mathrm{k}_{\mathrm{C}}
$$

where $k_{A}, k_{B}, k_{C}-$ absorption coefficients $\left[\mathrm{m}^{-1}\right]$ at the measuring points.

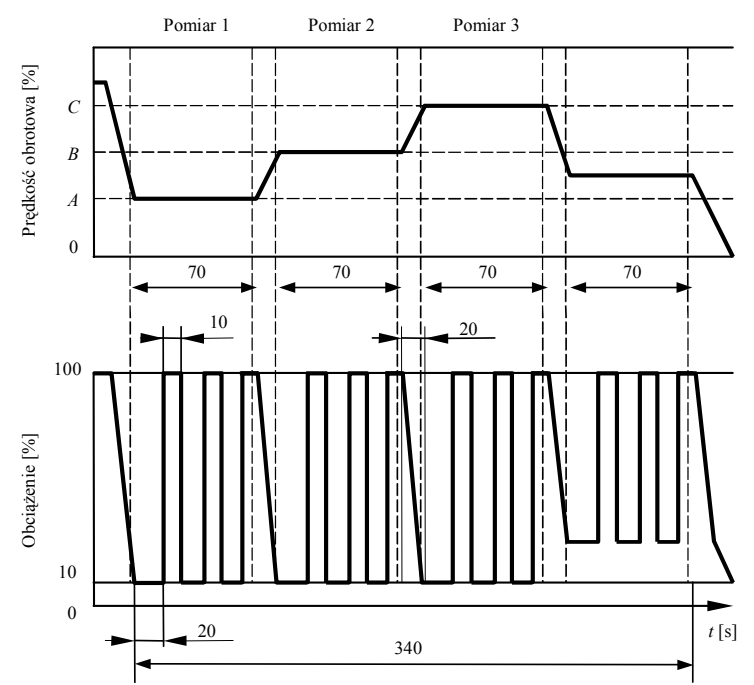

Fig. 3. The schematics of the European ELR opacity test Rys. 3. Schemat europejskiego testu ELR dotyczącego pomiaru zaczernienia spalin

The ETC test performed as the dynamic one is determined by the engine speed and torque as a function of time. The duration of the test is $1800 \mathrm{~s}$ and we can distinguish three parts in it:

- the first one - reflecting the city driving conditions with the maximum speed of $50 \mathrm{~km} / \mathrm{h}$ (drive-off, stop and idle),

- the second one - suburban driving with gradual acceleration - average speed is $72 \mathrm{~km} / \mathrm{h}$,

- the third one - reflecting the expressway driving average speed is $88 \mathrm{~km} / \mathrm{h}$.

This test is developed so as to be carried out on an engine dynamometer (Fig. 4; at given engine speed and torque) or a chassis dynamometer (at given vehicle speed in $\mathrm{km} / \mathrm{h}-$ Fig. 5). For the certification tests engine test is required.

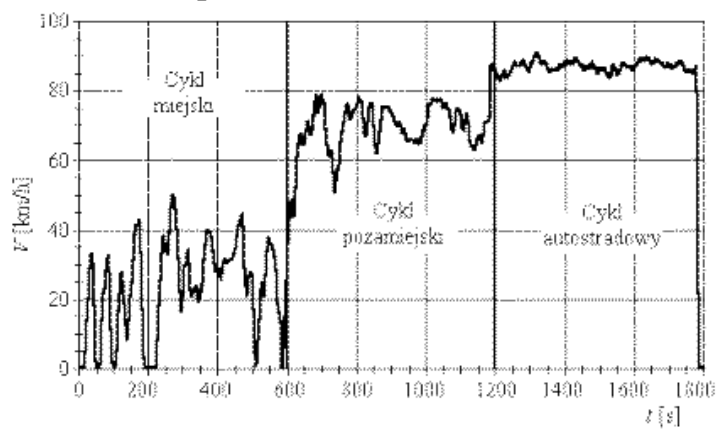

Fig. 5. Schematics of the ETC test performed on the engine dynamometer

Rys. 5. Schemat testu ETC wykonywanego na hamowni podwoziowej

$$
\begin{aligned}
& \mathrm{A}=\mathrm{n}_{\text {min }}+0,25\left(\mathrm{n}_{\text {max }}-\mathrm{n}_{\text {min }}\right), \\
& \mathrm{B}=\mathrm{n}_{\text {min }}+0,50\left(\mathrm{n}_{\text {max }}-\mathrm{n}_{\text {min }}\right), \\
& \mathrm{C}=\mathrm{n}_{\text {min }}+0,75\left(\mathrm{n}_{\text {max }}-\mathrm{n}_{\text {min }}\right) .
\end{aligned}
$$

Łącznie $\mathrm{z}$ testem ESC jest wykonywany pomiar zaczernienia spalin w teście ELR (rys. 3) - charakterystyczne punkty pomiarowe określono na podstawie schematu testu ESC. Wartość współczynnika absorpcji (k) określa się na podstawie formuły obliczeniowej:

$$
\mathrm{k}=0,43 \mathrm{k}_{\mathrm{A}}+0,56 \mathrm{k}_{\mathrm{B}}+0,01 \mathrm{k}_{\mathrm{C}},
$$

gdzie $k_{A}, k_{B}, k_{C}-$ współczynniki absorpcji $\left[\mathrm{m}^{-1}\right] \mathrm{w}$ punktach pomiarowych.

Test ETC wykonywany jako dynamiczny, jest określony przez prędkość obrotową silnika i moment obrotowy w funkcji czasu. Czas trwania testu wynosi 1800 s i można wyodrębnić w nim trzy części:

- pierwsza - reprezentująca jazdę miejską z maksymalną prędkością $50 \mathrm{~km} / \mathrm{h}$ (ruszanie $\mathrm{z}$ miejsca, zatrzymanie i praca silnika na biegu jałowym),

- druga - jazda podmiejska ze stopniowym przyspieszaniem - średnia prędkość $72 \mathrm{~km} / \mathrm{h}$,

- trzecia - reprezentująca jazdę autostradową - średnia prędkość $88 \mathrm{~km} / \mathrm{h}$.

Test ten jest przygotowany jako wykonywany na hamowni silnikowej (rys. 4; określona prędkość obrotowa - moment obrotowy) lub na hamowni podwoziowej (określona prędkość pojazdu $\mathrm{w} \mathrm{km} / \mathrm{h}$ - rys. 5). Do badań certyfikacyjnych jest wymagany test silnikowy.

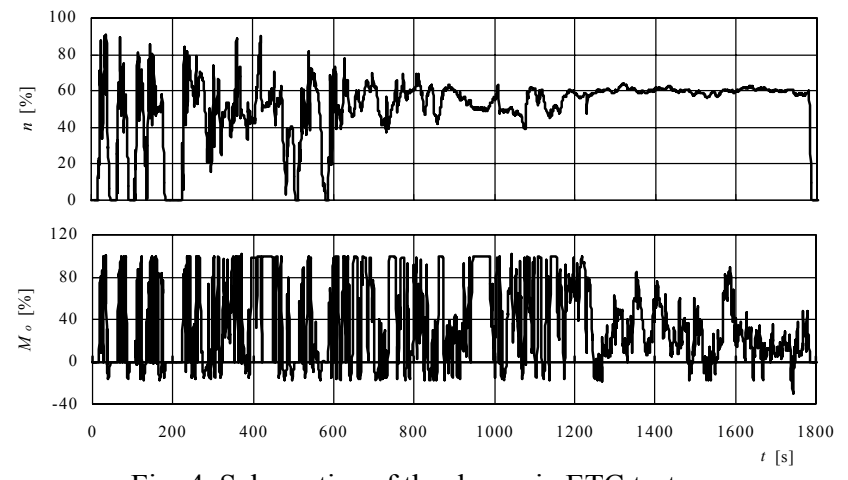

Fig. 4. Schematics of the dynamic ETC test (negative torque representing external drive)

Rys. 4. Schemat dynamicznego testu ETC (ujemny moment reprezentuje obcy napęd)

\section{Metodyka badań emisji związków szkodliwych spalin}

Wykonano pomiary parametrów pracy silnika oraz jazdy autobusu z konwencjonalnym układem napędowym. Pomiary te przeprowadzono w warunkach drogowych, w warunkach ruchu miejskiego w Poznaniu (rzeczywiste warunki eksploatacji autobusu miejskiego). Należy podkreślić, że badania w rzeczywistych warunkach eksploatacji są jednym s głównych kierunków rozwoju metod badań i coraz bardziej zyskują na znaczeniu [1-5]. Trasę przejazdu przedstawiono na rysunku 6. Badania przeprowadzono podczas jazdy autobusu po ulicach miasta trasą przybliżoną do typo- 


\section{Methodology of the exhaust emission tests}

The engine and vehicle driving parameters were measured on a bus fitted with a conventional powertrain. The measurements were carried out in road conditions in the city traffic in Poznan (actual operating conditions of the bus). It is noteworthy that the tests carried out in the actual operating conditions represent the main trends in the measurement methodology and they are gaining in importance [1-5]. The test route has been presented in figure 6 . The tests were performed in the city traffic on a route similar to the actual bus routes of the Poznan bus operator. The test was performed in the morning and around noon. The conditions were selected so as to ensure the most accurate reflection of the actual bus operating conditions: traffic similar to that on a bus route (average traffic of the Poznan routes). The tests were conducted for two days (Friday and Saturday). The days were characterized of very high and very low number of transported people and high and medium traffic congestion respectively. The object of the investigations was Solaris Urbino 18 fitted with a conventional powertrain. This was an 18-meter articulated vehicle. During the tests the engine and the driving parameters were recorded continuously as sent from the diagnostic system of the vehicle and the GPS.

For the tests the authors used a portable exhaust emission analyzer SEMTECH DS (fig. 7 - 8) manufactured by Sensors Inc PEMS (portable emissions measurement system). The exhaust sample is taken through a probe and supplied by a heated line maintaining the temperature of $191^{\circ} \mathrm{C}$. Subsequently, the exhaust gases are filtered out of the particulate matter (diesel engine only). Then the measurement of the concentration of hydrocarbons is carried out in the FID (Flame Ionization Detector). The sample is cooled down to the temperature of $4^{\circ} \mathrm{C}$ and in the NDUV (Non-Dispersive Ultraviolet) analyzer the measurement of the nitric monoxides and nitric dioxides is performed and in the NDIR (Non-Dispersive Infrared) the concentration of

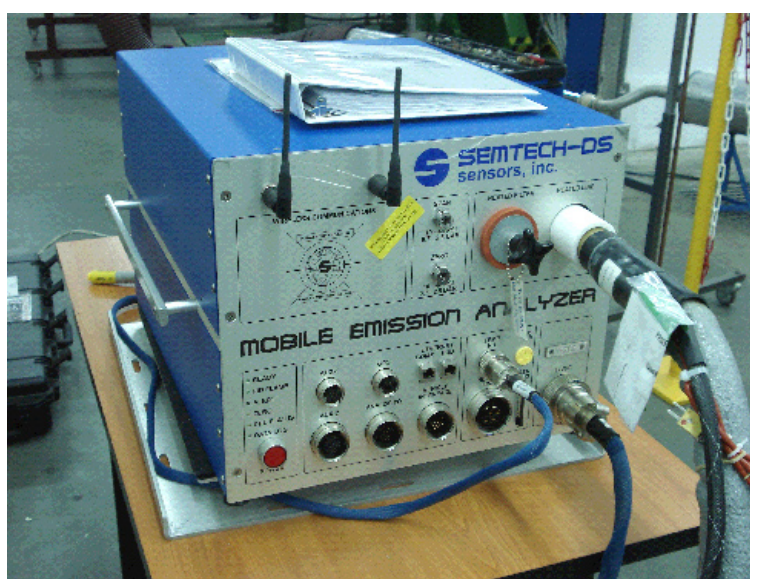

Fig. 7. SEMTECH DS measurement device Rys. 7. Analizator SEMTECH DS. wej, jaką pokonują autobusy linowe Miejskiego Przedsiębiorstwa Komunikacyjnego. Badania wykonano w godzinach porannych i południowych (tab. 5). Warunki tak dobrano, aby istniała możliwość jak największego odwzorowania rzeczywistych warunków ruchu: obciążenie podobne do obciążenia autobusu liniowego, było zgodne ze średnim obciążeniem linii poznańskich. Badania prowadzono w dwóch dniach (piątek i sobota), charakterystycznych (odpowiednio) dla bardzo dużej (małej) liczby przewożonych pasażerów i dużego (średniego) natężenia ruchu drogowego. Obiektami badań były autobus Solaris Urbino 18 wyposażony $\mathrm{w}$ napęd konwencjonalny. Był to autobus 18-metrowy, przegubowy. Podczas badań w sposób ciaggły rejestrowano parametry pracy silnika i jazdy pojazdu bezpośrednio przesyłane $\mathrm{z}$ systemu diagnostycznego pojazdu oraz z systemu lokalizacji GPS.

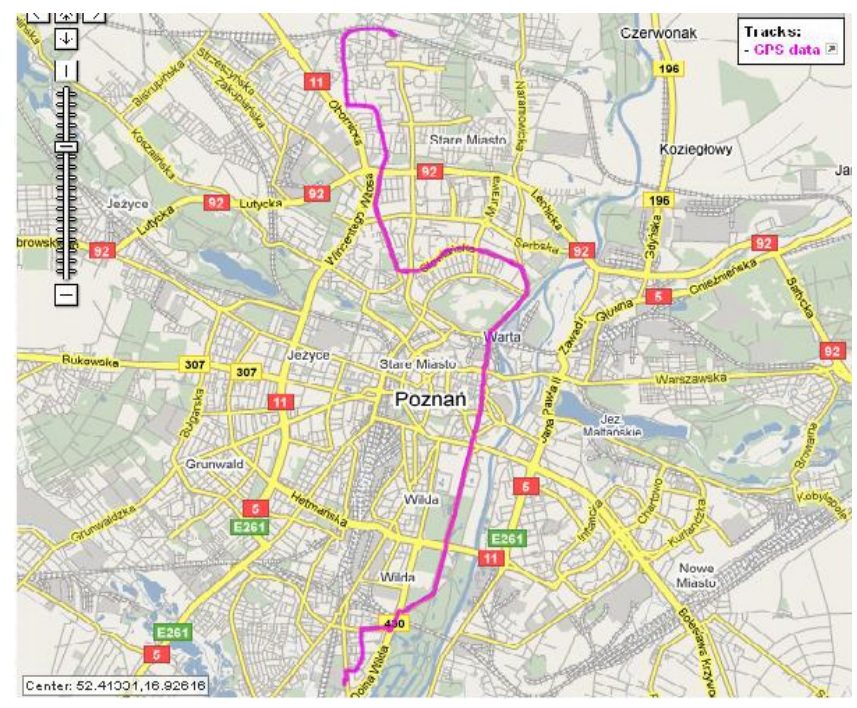

Fig. 6. The road portion used for the exhaust emission tests [www.gpswisualizer.com]

Rys. 6. Odcinek pomiarowy drogi wykorzystany do badań emisyjności [wykonano na podstawie www.gpswisualizer.com]

Do badań został wykorzystany mobilny przyrząd do pomiaru toksyczności spalin SEMTECH DS (rys. 7 8) amerykańskiej firmy SENSORS Inc, która jest jedną $\mathrm{z}$ dwóch firm przodujących w budowie tego typu przyrządów. Umożliwiał on pomiar zużycia paliwa, stężenie toksycznych związków spalin oraz masowego natężenia przepływu. Według schematu (rys. 12) próbka spalin pobierana jest przez sondę masowego natężenia spalin i dostarczana do przyrządu tzw. drogą grzana, która utrzymuję temperaturę $191^{\circ} \mathrm{C}$. Spaliny zostają filtrowanie $\mathrm{z}$ cząstek stałych (w przypadku silników ZS) i dokonywany jest pomiar stężenia węglowodorów w analizatorze FID (Flame Ionization Detector). Następnie próbka jest schładzana do $4^{\circ} \mathrm{C}$ i w analizatorze NDUV (Neodyspersion Detector Ultra Violet) dokonywany jest pomiar stężenia tlenków azotu i dwutlenków azotu, a w analizatorze NDIR (Neodyspersion Detector Infra Red) mierzone jest stężenie tlenku węgla oraz dwutlenku węgla. Pomiar tlenu 
carbon monoxide is measured. The measurement of oxygen is carried out through an electrochemical sensor. Semtech also records parameters taken from the vehicle OBD and GPS (Global Positioning System). The analyzer can be controlled by a personal computer and through a wired or wireless connection.

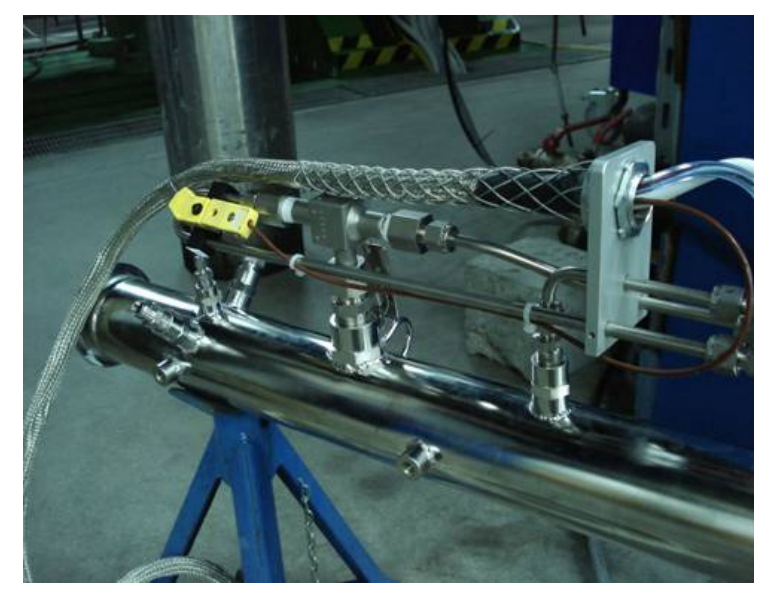

Fig. 8. Mass flow meter measuring the exhaust mass flow

Rys. 8. Przepływomierz do pomiaru masowego natężenia spalin

\section{Results and analysis}

Based on the exhaust emission level characteristics of the bus fitted with the conventional powertrain the share of the emissions was determined depending on the engine parameters as well as the driving parameters during the whole test. The operating range of the vehicle was within the speeds of $0-16 \mathrm{~m} / \mathrm{s}(0-60 \mathrm{~km} / \mathrm{h})$ and accelerations of $-0,3 \mathrm{~m} / \mathrm{s}^{2}-0,3 \mathrm{~m} / \mathrm{s}^{2}$. A great share of the vehicle operation in the urban traffic was at idle (the share amounts to 33\%) while for higher speed ranges of $8-14 \mathrm{~m} / \mathrm{s}$ the operating time-share was approximately $20 \%$.

The greatest emission of carbon monoxide for the bus fitted with the conventional powertrain (Fig. 9) occurred for low speeds $(2-6 \mathrm{~m} / \mathrm{s})$. The range of acceleration for which an increase in the emission of $\mathrm{CO}$ occurred is wider - this is the range of $-1,5-2,7$ $\mathrm{m} / \mathrm{s}^{2}$.

Very similar to the emission of $\mathrm{CO}$ was the emission of HC (Fig. 10). The difference is that the range of accelerations for which the increased $\mathrm{HC}$ emission was observed was a bit narrower but the range of speeds was wider. The maximum values of the $\mathrm{HC}$ and $\mathrm{CO}$ emissions occurred for the same speeds and accelerations of the bus.

The greatest area for the $\mathrm{NO}_{\mathrm{x}}$ emission occurred for the medium speeds and great accelerations of the bus (Fig. 11). When comparing the area of increased emission of $\mathrm{NO}_{\mathrm{x}}$ with the area of $\mathrm{CO}$ and $\mathrm{HC}$ the area of $\mathrm{NO}_{\mathrm{x}}$ is greater. Besides, we can see that the emission of $\mathrm{NO}_{\mathrm{x}}$ increased as the acceleration of the bus grew and got reduced when the bus increased its speed. dokonywany jest za pomocą elektrochemicznego czujnika. Przyrząd posiada możliwość rejestracji parametrów odczytywanych z systemu diagnostycznego pojazdu i położenia geograficznego wykorzystującego moduł GPS. Przyrząd może być sterowany przez komputer osobisty po przez połączenie bezprzewodowe lub przewodowej.

\section{Wyniki badań $i$ ich analiza}

$\mathrm{Na}$ podstawie charakterystyki emisyjności pracy autobusu z napędem konwencjonalnym wyznaczono udziały emisji poszczególnych związków toksycznych spalin w zależności od parametrów pracy silnik i parametrów jezdnych podczas trwania całego testu. Zakres pracy pojazdu występuje w obszarze prędkości 0-16 $\mathrm{m} / \mathrm{s}(0-60 \mathrm{~km} / \mathrm{h})$ oraz $\mathrm{w}$ zakresie przyśpieszeń na poziomie $-0,3 \mathrm{~m} / \mathrm{s}^{2}$ do $0,3 \mathrm{~m} / \mathrm{s}^{2}$. Znaczny udział czasu pracy pojazdu w jeździe miejskiej przypada na zakres pracy biegu jałowego, którego udział wynosi 33\%, natomiast dla wyższego zakresu prędkości z przedziału $8-14 \mathrm{~m} / \mathrm{s}$ udział czasu pracy wynosi około $20 \%$.

Największa emisja sekundowa tlenku węgla dla autobusu z napędem konwencjonalnym (rys. 9) przypada na niski zakres prędkości (2-6 m/s). Szerszy jest zakres przyspieszeń w których występuje zwiększona emisja $\mathrm{CO}$, jest to obszar od $-1,5-2,7 \mathrm{~m} / \mathrm{s}^{2}$.

Bardzo podobny charakter do emisji CO ma emisja HC (rys 10). Różnica polega na tym, że niecą węższy jest zakres przyspieszeń autobusu dla którego zaobserwowano większą emisję HC, natomiast szerszy jest zakres prędkości pojazdu charakteryzujący się zwiększoną emisją. Wartości maksymalne emisji HC i CO występują dla tych samych prędkości i przyspieszeń autobusu.

Największy obszar emisji $\mathrm{NO}_{\mathrm{x}}$ przypada dla średniego zakresu prędkości oraz dla dużych przyśpieszeń autobusu (rys. 11). Porównując obszar zwiększonej emisji $\mathrm{NO}_{\mathrm{x}} \mathrm{z}$ obszarem charakterystycznym dl CO i HC jest on zdecydowanie większy. Ponadto wyraźnie jest zauważalne, że emisja $\mathrm{NO}_{\mathrm{x}}$ zwiększa się wraz ze zwiększaniem przyspieszenia autobusu i maleje ze zwiększaniem prędkości autobusu.

Dla autobusu z napędem konwencjonalnym największa emisja sekundowa CO występuje dla zakresu dużych prędkości obrotowych silnika przy maksymalnym obciążeniu (rys. 12). jest to zakres pracy silnika który nie jest często wykorzystywany. Zakres wykorzystywanych prędkości obrotowych zawiera się w przedziale do $1800 \mathrm{obr} / \mathrm{min}$ i jest mniejszy od prędkości maksymalnej silnika, która wynosi $2500 \mathrm{obr} / \mathrm{min}$. Obszar sekundowej emisji HC przypada na bardzo duży zakres prędkości obrotowej (od 1000-1800 obr/min), przy jednoczesnym wysokim zakresie obciążeń silnika (800-1300 Nm, rys. 13). Zauważalne jest podobieństwo występowania największej emisji HC i CO w tym samym zakresie prędkości obrotowej i obciążenia silnika. 


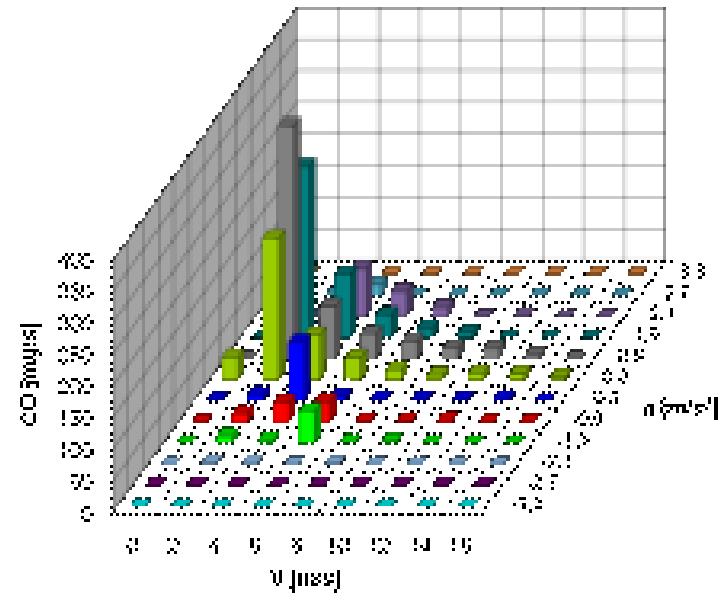

Rys. 9. Charakterystyka emisji CO w zależności od prędkości jazdy i przyspieszenia autobusu

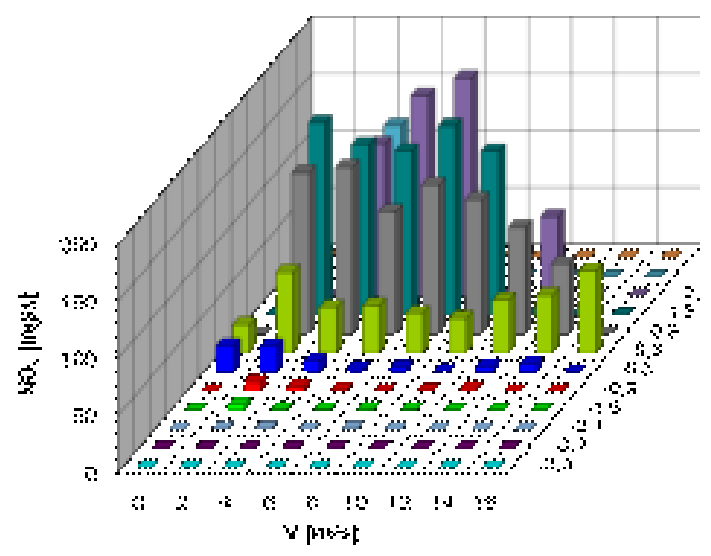

Rys. 11. Charakterystyka emisji $\mathrm{NO}_{\mathrm{x}} \mathrm{w}$ zależności od prędkości jazdy i przyspieszenia autobusu

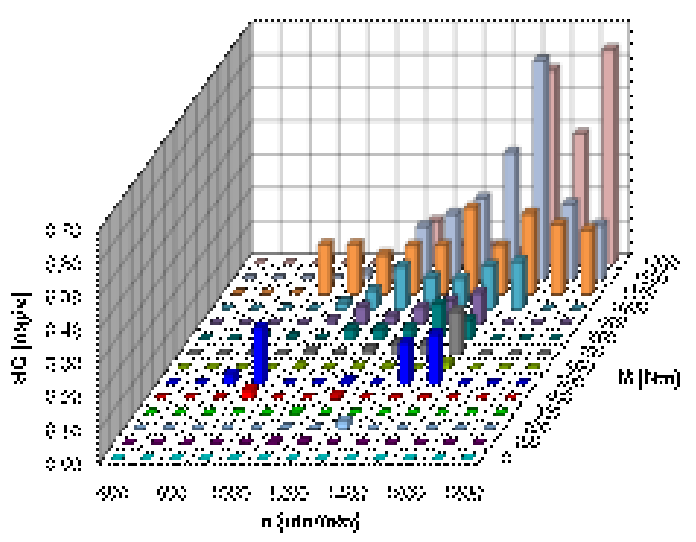

Rys. 13. Charakterystyka emisji HC w zależności od prędkości obrotowej wału korbowego i obciążenia silnika

For the bus fitted with the conventional powertrain the greatest $\mathrm{CO}$ emission occurred for the range of high engine speeds and maximum engine loads (Fig. 12). This was the engine operating range that is not frequently used. The range of the frequently used engine speeds is up to $1800 \mathrm{rpm}$ and is lower than the maximum engine speed, which is $2500 \mathrm{rpm}$.

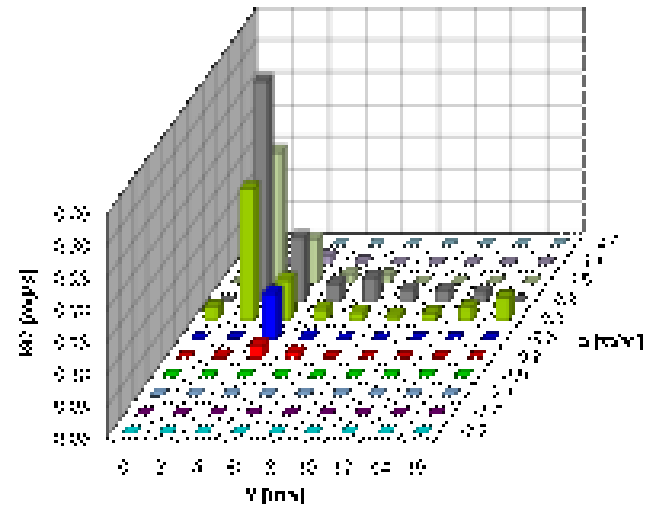

Rys. 10. Charakterystyka emisji HC w zależności od prędkości jazdy i przyspieszenia autobusu

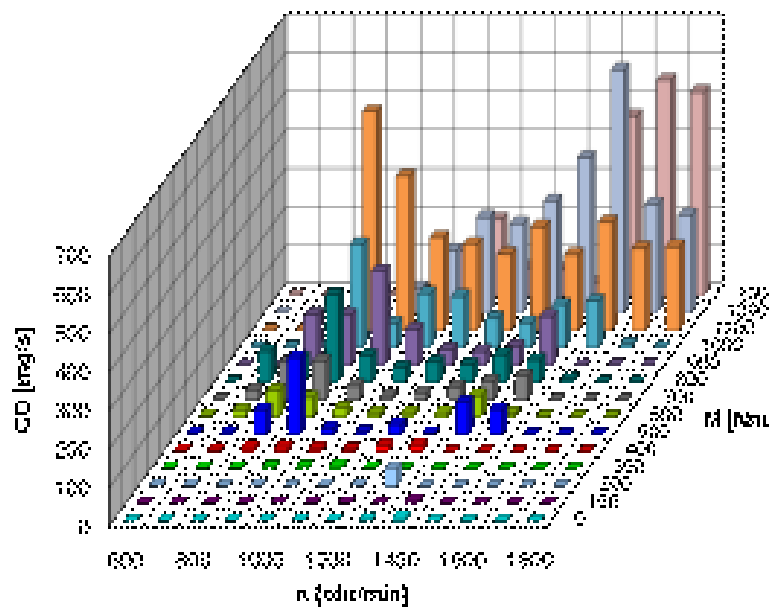

Rys. 12. Charakterystyka emisji CO w zależności od prędkości obrotowej wału korbowego i obciążenia silnika

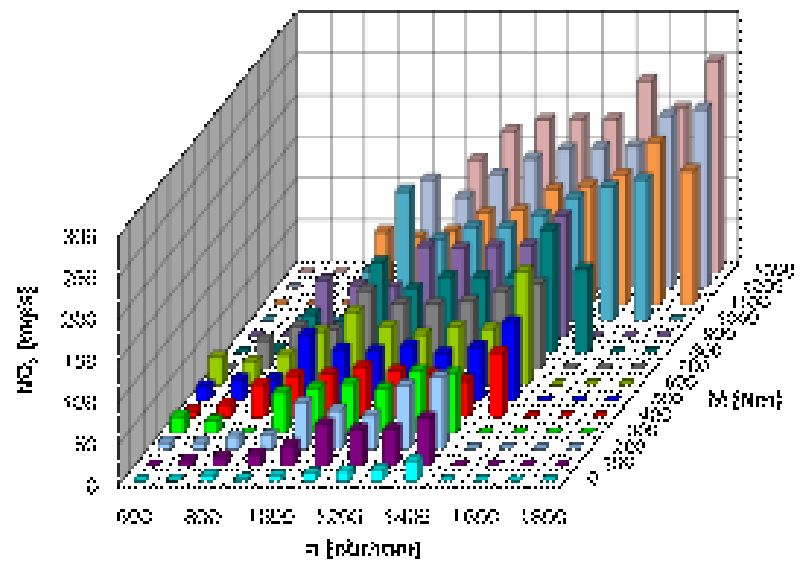

Rys. 14. Charakterystyka emisji $\mathrm{NO}_{\mathrm{x}}$ w zależności od prędkości obrotowej wału korbowego i obciążenia silnika 
The area of the $\mathrm{HC}$ emission fell in a very wide engine speed range (from 1000-1800 rpm) at high engine loads (800-1300 Nm, Fig. 13). The similarity in the occurrence of the greatest emission of $\mathrm{HC}$ and $\mathrm{CO}$ in the same range of engine speeds and loads was visible. The area of the greatest emission of $\mathrm{NO}_{\mathrm{x}}$ occurred for the greatest engine speeds and loads (Fig. 14). It is characteristic that the emission of $\mathrm{NO}_{\mathrm{x}}$ increased proportionally to the increase in the engine speed and load. A very little emission of $\mathrm{NO}_{\mathrm{x}}$ occurred in the engine speed range of 1500-1800 rpm and low and medium loads (up to approximately $800 \mathrm{Nm}$ ).

The greatest emission rate of carbon dioxide (fuel consumption) in the tested conditions of city traffic could be observed for the maximum values of loads and engine speeds. The $\mathrm{CO}_{2} /$ fuel consumption rate grew as the engine speed and load increased (Fig. 15).

The authors also performed an analysis of the changes of the exhaust emissions under dynamic conditions depending on the speed of the bus. The emission of CO (Fig. 16) did not exceed $1000 \mathrm{mg} / \mathrm{s}$. Its level in the beginning of the test was relatively low because the measurement took place on a hot engine (cold start was not recorded). The same situation occurred for the emission of HC (Fig. 17). As the speed of the vehicle grew the emission of $\mathrm{NO}_{\mathrm{x}}$ increased (Fig. 18) and its level did not exceed $400 \mathrm{mg} / \mathrm{s}$. The greatest value of the emission of $\mathrm{CO}_{2}$ (Fig. 19) amounted to approximately $40 \mathrm{~g} / \mathrm{s}$ (at high vehicle speeds) and its average level remained at $20 \mathrm{~g} / \mathrm{s}$. From the presented relations it results that the greatest exhaust emissions occurred when the bus accelerated and drove at high speeds.

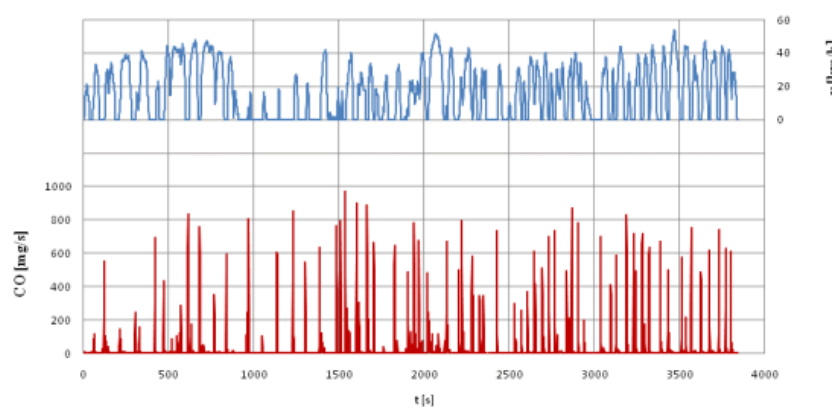

Rys. 16. Sekundowa emisja CO oraz prędkość autobusu z napędem konwencjonalnym

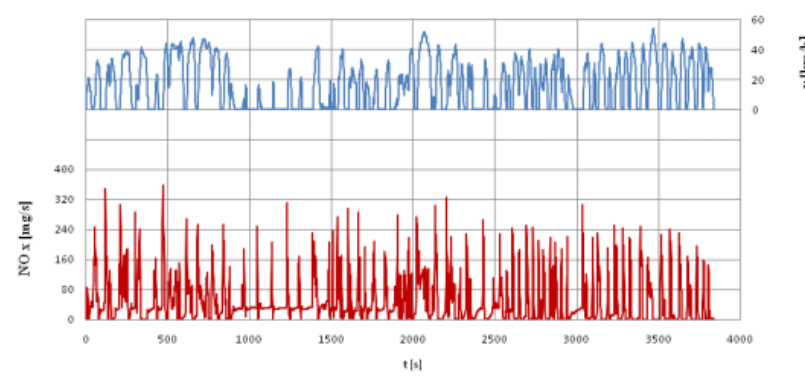

Rys. 18. Emisja sekundowa $\mathrm{NO}_{\mathrm{x}}$ oraz prędkość autobusu z napędem konwencjonalnym obciążeń silnika (do około $800 \mathrm{Nm}$ ).

Największe natężenie emisji dwutlenku węgla/zużycie paliwa w badanych warunkach ruchu miejskiego można zaobserwować dla maksymalnych wartości obciążenia i prędkości obrotowej wału korbowego silnika. Natężenie $\mathrm{CO}_{2}$ /zużycie paliwa zwiększa się wraz ze wzrostem prędkości obrotowej i obciążenia silnika (rys. 15).

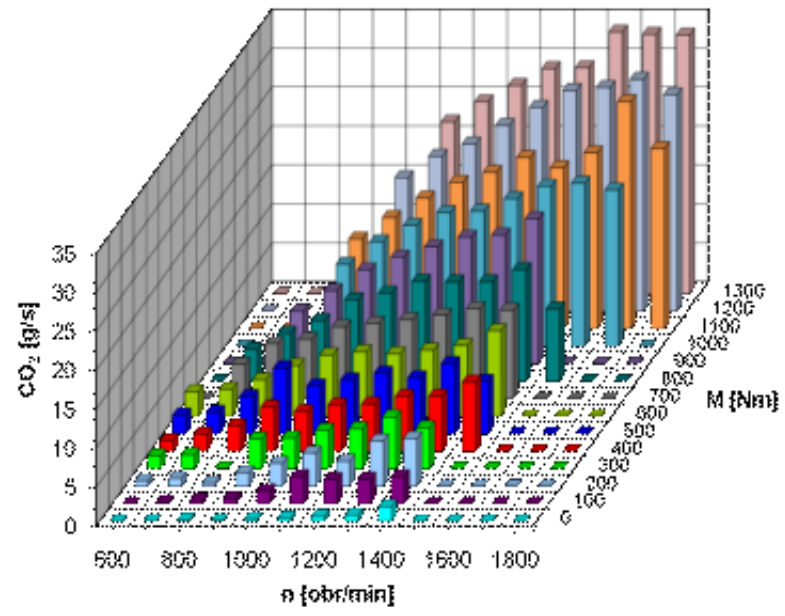

Fig. 15. Time density characteristics of the emission of $\mathrm{CO}_{2}$ from the bus

Rys. 15. Charakterystyka gęstości czasowej emisji $\mathrm{CO}_{2}$ autobusu Wykonano także analizę zmian emisji związków toksycznych w warunkach dynamicznych, w zależności od prędkości jazdy autobusu. Emisja sekundowa CO (rys. 16) nie przekracza $1000 \mathrm{mg} / \mathrm{s}$. Jej poziom na początku testu jest relatywnie niski, ponieważ pomiar odbywał się na rozgrzanym silniku, a więc nie zarejestrowano zimnego rozruchu. Taka sama sytuacja jest $\mathrm{w}$

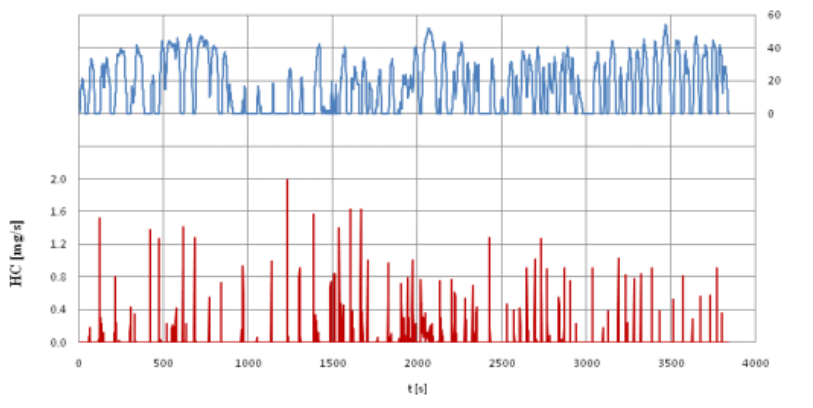

Rys. 17. Sekundowa emisja HC oraz prędkość autobusu z napędem konwencjonalnym

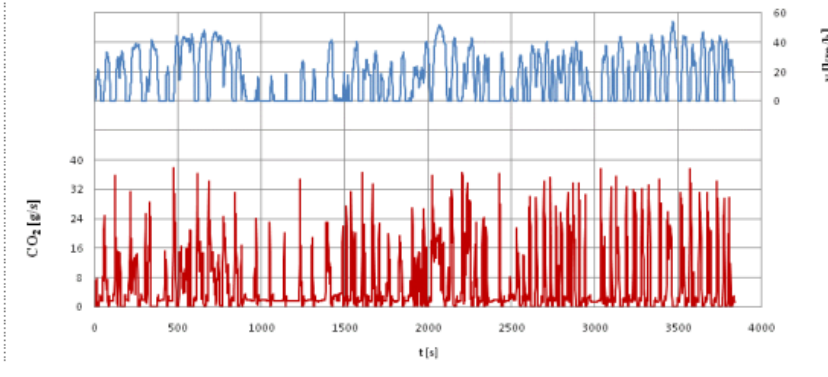

Rys. 19. Sekundowa emisja $\mathrm{CO}_{2}$ oraz prędkość autobusu z napędem konwencjonalnym 


\section{Conclusions}

1. From the presented relations it results that the areas of the greatest emissions of $\mathrm{CO}, \mathrm{HC}$ and $\mathrm{NO}_{\mathrm{x}}$ did not overlap with the most frequently used areas of operation of the bus engine (engine speed and engine load).

2. The greatest emission of $\mathrm{CO}$ occurred in the whole range of used engine speeds (up to $1800 \mathrm{rpm}$ ) and at high engine loads $(800 /-1300 \mathrm{Nm})$ in the same areas of engine operation for the highest engine speeds and loads.

3. The greatest emission of $\mathrm{HC}$ occurred for the areas of high engine loads (from 900 to $1300 \mathrm{Nm}$ ) and high engine speeds (1200 to $1800 \mathrm{rpm}$ ). The range of the emission of $\mathrm{HC}$ was similar to the emission of $\mathrm{CO}$ but there was a narrower range of engine speeds.

4. The emission of $\mathrm{NO}_{\mathrm{x}}$ grew proportionally to the increase of the engine speed and engine load and was similar to $\mathrm{CO}_{2}$ /fuel consumption.

5. The greatest exhaust emissions were observed when the bus accelerated and drove at high speeds. The driving at constant speed generated lower exhaust emissions and resulted in lower fuel consumption.

\section{Bibliography / Bibliografias}

1. AVL, Current and Future Exhaust Emission Legislation, AVL List GmbH, Graz 2019.

2. Merkisz J., Mazurek S.: Pokładowe systemy diagnostyczne pojazdów samochodowych, WKiE, Warszawa 2007.

3. Merkisz, J., \& Rymaniak, t. (2017). The assessment of vehicle exhaust emissions referred to $\mathrm{CO} 2$ based on the investigations of city buses under actual conditions of operation. Eksploatacja i Niezawodność, 19.

4. Rymaniak, Lukasz. "Comparison of the combustion engine operating parameters and the ecological indicators of an urban bus in dynamic type approval tests and in actual operating conditions." MATEC Web of Conferences. Vol. 118. EDP Sciences, 2017.

5. Rymaniak, Lukasz, et al. "Method of determining the locomotive engine specific fuel consumption based on its operating conditions." AIP Conference Proceedings. Vol. 2078. No. 1. AIP Publishing LLC, 2019. przypadku emisji sekundowej HC (rys. 17). Wraz ze wzrostem prędkości pojazdu wzrasta emisja sekundowa $\mathrm{NO}_{\mathrm{x}}$ (rys. 18) i jej poziom nie przekracza $400 \mathrm{mg} / \mathrm{s}$. Największa wartość emisji sekundowej $\mathrm{CO}_{2}$ wynosi około $40 \mathrm{~g} / \mathrm{s}$ (przy dużych prędkościach pojazdu), natomiast jej średni poziom utrzymuje się w granicach $20 \mathrm{~g} / \mathrm{s}$. Z przedstawionych zależności wynika, że największa emisja związków toksycznych spalin występuje podczas przyspieszania autobusu i jazdy z dużymi prędkościami.

\section{Wnioski}

a. Z przedstawionych zależności wynika, że obszary największej emisji $\mathrm{CO}, \mathrm{HC}, \mathrm{NO}_{\mathrm{x}}$ nie pokrywaja się z najczęściej wykorzystywanymi obszarami pracy silnika autobusu (zakres prędkości obrotowej wału korbowego i obciążenie silnika).

b. Największa emisja CO występuje w całym zakresie wykorzystywanych prędkości obrotowych (do $1800 \mathrm{obr} / \mathrm{min})$ i dla dużych obciążeń silnika $(800$ do $1300 \mathrm{Nm}$ ). tych samych obszarach pracy silnika, dla największej prędkości obrotowej wału korbowego i największego obciążenia.

c. Największa emisja HC występuje w obszarze dużych obciążeń silnika (od 900 do $1300 \mathrm{Nm}$ ) i dużych prędkości obrotowych silnika 1200 do $1800 \mathrm{obr} / \mathrm{min}$. Zakres emisji HC jest podobny do zakresu emisji CO, jednak charakteryzuje się mniejszym zakresem prędkości obrotowej.

d. Emisja $\mathrm{NO}_{\mathrm{x}}$ zwiększa się proporcjonalnie wraz ze zwiększaniem prędkości obrotowej wału korbowego i obciążenia silnika i ma podobny charakter jak emisja $\mathrm{CO}_{2}$ /zużycia paliwa.

e. Największą emisję związków toksycznych spalin zaobserwowano podczas przyspieszania i jazdy autobusu z dużymi prędkościami. Natomiast jazda ze stałą prędkością generuje mniejszą emisję związków toksycznych spalin i mniejsze zużycie paliwa. 